\title{
Soil Erosion and Sediment Yield of a Sanitary Landfill Site - A Case Study
}

\author{
Oon, Y.W. ${ }^{1}$, Chin, N.J. ${ }^{2}$ and Law, P.L. ${ }^{3}$
}

\begin{abstract}
This research presents the results of a study on soil erosion rates and sediment yields of a proposed Level 4 Sanitary Landfill construction site located in Sibu, Sarawak. Assessments on potential soil erosion rates and sediment yields during pre-construction, construction and operation stages were carried out using the Revised Universal Soil Loss Equation (RUSLE) and Modified Universal Soil Loss Equation (MUSLE), respectively. It was found that soil erosion rates during construction and operation stages fell under "Moderately High" category, whereby highest sediment yield occurred during construction and operation stages. Comparative analysis on with and without Best Management Practices (BMPs) during construction stage demonstrated that BMPs could significantly reduce the rate of soil erosion, and thus sediment yields.
\end{abstract}

Keywords: Soil erosion rate, sediment yield, construction, RUSLE, MUSLE, BMPs

\section{INTRODUCTION}

$\mathrm{I}_{\mathrm{n}}$ In Malaysia, there has been an increasing concern over soil erosion due to deforestation, land conversion for highway, logging activities, industrial or urbanization purposes [1]. Runoff erosivity has been the most significant erosion factor due to high mean of annual rainfall, storm frequency and density [2]. The objectives of this research are to estimate and compare soil erosion rates and sediment yields during preconstruction, construction, and operation stages of a sanitary landfill at Sibu, Sarawak.

The proposed Level 4 Sanitary Landfill is located approximately $26 \mathrm{~km}$ from Sibu Town centre (Figure 1). It is a Level 4 Sanitary Landfill located at Jalan Kemuyang, Sibu, Sarawak. Comprehensive assessments on the rates of erosion and sediment yields were carried out during pre-construction, construction and post-construction stages. The topography of the region comprises of generally rolling and flat lands, well-drained by tributaries of Sg. Lukut running along the northeast boundary of the proposed landfill site (Figure 1). There are relatively lower spots at the north part of the landfill site, mainly swampy land. The landfill area is predominantly underlain by Tertiary Eocene sediments; namely Pelagus Formation and a small portion by Pleistocene-Holocene sediments.

The two main streams draining the site catchment are Sungai Lukut and Sungai Pasai, whereby Sungai Lukut is the tributary of Sungai Pasai. The annual rainfall pattern varies from year-to-year with distinct dry and wet seasons, which shows the characteristic influence of the monsoon seasons. The region experiences rather heavy rainfall during the peak of the Northeast monsoon, receiving more than $400 \mathrm{~mm}$ in December and $500 \mathrm{~mm}$ in January. The total annual rainfall is relatively high that varies between $110.2 \mathrm{~mm}$ during the El Nino years to above $4,500 \mathrm{~mm}$ during the wet years.

\footnotetext{
${ }^{1}$ Oon, Y.W., Student of Civil Engineering Department, Universiti Malaysia Sarawak (e-mail: yinwee3@yahoo.com)

${ }^{2}$ Chin, N.J., Student of Civil Engineering Department, Universiti Malaysia Sarawak (e-mail: chin_17@live.com )

${ }^{3}$ Law, P.L., Prof, Civil Engineering Department, Universiti Malaysia Sarawak (e-mail: puonglaw@ @eng.unimas.my)
} 


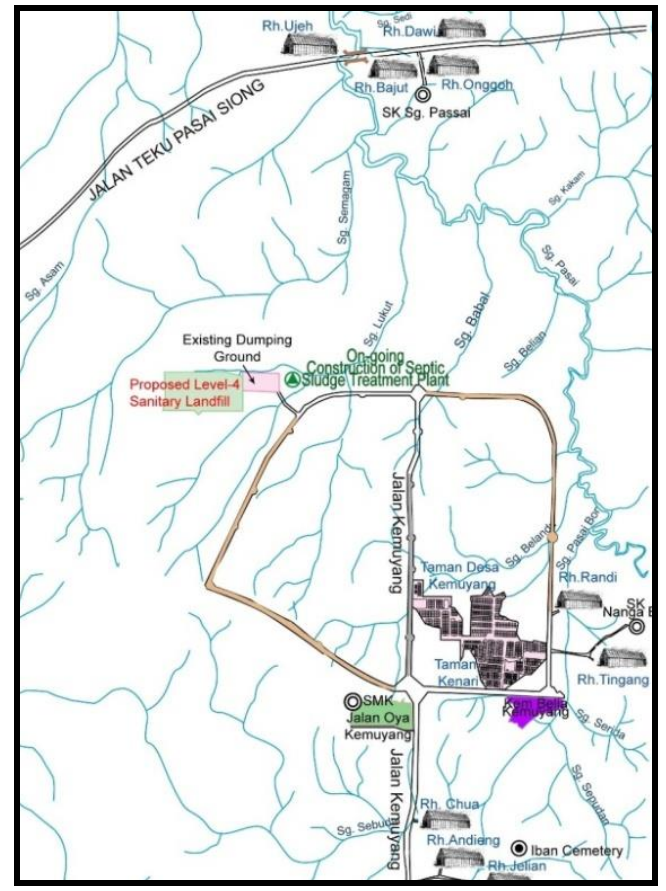

Figure 1: Locality of Proposed Level 4 Sanitary Landfill, Jln Kemuyang, Sibu

Since, the early 1980s, the United States Department of Agriculture (USDA) has used the Universal SoilLoss Equation (USLE) to estimate the severity of soil and sediment yield from disturbed land surface. Lately, a refined and revised equation called Revised Universal Soil-Loss Equation (RUSLE) that can be applied to many more field conditions, provides much more site-specific value than does the USLE, and to overcome major limitations of the USLE for predicting rainfall erosion losses. Generally, the RUSLE equation can be written as follow:

$$
\text { RUSLE }=R \times K \times L S \times C \times P
$$

where, $\quad$ RUSLE $=$ Average annual soil loss in unit [tons.(ha.yr) ${ }^{-1}$ ]

$\mathrm{R}=$ Rainfall/runoff erosivity in unit $\left[\mathrm{Mj} . \mathrm{mm} .\left(\right.\right.$ ha.h.yr) $\left.{ }^{-1}\right]$

$\mathrm{K}=$ Soil erodibility in unit [tons.ha.h.(ha.Mj.mm) ${ }^{-1}$ ]

$\mathrm{LS}=$ Slope length and steepness factor

$\mathrm{C}=$ Cover-management factor

$\mathrm{P}=$ Erosion control practice factor

In this study, the R factor was estimated using Foster's Method according to the following equation [4]:

$$
\mathrm{R}=0.276 \mathrm{P} \times\left(\frac{I_{30}}{173} \cdot 6\right)
$$

where,

$$
\begin{aligned}
& \mathrm{P}=\text { mean annual rainfall in mm, and } \\
& I_{30}=\text { maximum } 30 \text {-minute rainfall intensity } .
\end{aligned}
$$

Appropriate LS value could be obtained from the following equation:

$$
\mathrm{LS}=\left(0.065=0.045 \mathrm{~S}+0.0065 \mathrm{~S}^{2}\right) \times \sqrt{\frac{L}{22} \cdot 13}
$$

where, $L$ is in metre (m) and $\mathrm{S}$ in percent $(\%)$. 
In additional to RUSLE equation, another soil loss equation was established in 1975, namely the Modified Universal Soil Loss Equation (MUSLE) or also called Single Event Sediment Yields [5]. In this equation, the rainfall energy or runoff erosivity factor, $\mathrm{R}$ in the USLE was replaced with a term that includes both the peak discharge and total amount volume of runoff applied to the field to determine the sediment yield during a specific storm event [5]. Generally, the MUSLE equation is expressed as:

$$
\text { MUSLE }=11.8 \times\left(\left(V \times Q_{p}\right)^{0} .56\right) \times K \times L S \times C \times P
$$

where

$$
\begin{aligned}
\text { MUSLE }= & \text { Sediment yield (tons) } \\
\mathrm{V}= & \text { Runoff volume }\left(\mathrm{m}^{3}\right) \\
\mathrm{Q}_{\mathrm{p}}= & \text { Peak runoff rate }\left(\mathrm{m}^{3} \cdot \mathrm{sec}^{-1}\right)
\end{aligned}
$$

The peak runoff rate can be determined by using rational formula with the equation described as follow:

$$
\mathbf{Q}_{\mathrm{p}}=\frac{C I A}{360}
$$

The runoff coefficient, $C$, represents the percentage of rainfall which is related to multiple hydrologic processes. In a non-homogeneous drainage area, $C$ should be calculated as an area-weighted composite of the different land uses in the watershed. The intensity, $I$ can be obtained from Rainfall Intensity, Duration and Frequency Curve (IDF Curves) [6]. $A$ is the drainage area. The IDF curve summarizes the conditional probabilities or frequencies of rainfall depth or average intensities at a particular location. These variables, i.e. intensity, duration and frequency are all related to each other [7].

The SCS Curve Number Runoff relates a calculated Runoff Curve Number (CN) to runoff, accounting for initial abstraction losses and infiltration rates of soils. The fundamentals rainfall-runoff equations are as follows [8]:

$$
Q_{p}=\frac{\left(\left[P-I_{a}\right)\right]^{2}}{\left(P-I_{a}\right)+S}
$$

Initial abstraction $\left(\mathrm{I}_{\mathrm{a}}\right)$ is all losses before runoff begins, which includes water retained in surface depressions, water intercepted by vegetation, evaporation, and infiltration. $I_{a}$ is highly variable but generally is correlated with soil and cover factors. From the previous studies on small agricultural watersheds, $I_{\mathrm{a}}$ can be approximated by the following empirical equation:

$$
I_{a}=0.2 S
$$

While $I_{a}$ is an independent parameter, this approximation allows the use of a combination of $S$ and $P$ to produce a unique runoff amount. Substituting (7) into (6) gives:

$$
Q_{p}=\frac{(P-0.2 S)^{2}}{P+0.8 S}
$$

$\mathrm{S}$ is related to the soil and cover conditions of the watershed as represented by the value of Runoff Curve Number $(\mathrm{CN})$. Generally, $\mathrm{CN}$ values range from 0 to 100 , and $\mathrm{S}$ is related to $\mathrm{CN}$ by:

$$
S=\left(\frac{1000}{\mathrm{CN}}\right)-10
$$

For a given $\mathrm{CN}$ and precipitation depth, the volume of runoff can be calculated using Equation 8 and Equation 9. The $\mathrm{CN}$ value can be expressed as a function of soil characteristics, hydrologic condition and cover or land use. For watersheds with multiple soil types or land uses, an area-weighted CN should be used. When significant differences in land use or natural control points exist, the watershed should be divided up into smaller drainage areas for modeling purposes. Many factors can affect the erosion and sedimentation processes especially in construction development. In this study, the RUSLE and MUSLE concepts were used as measurements of soil erosion for specific combinations of physical and 
management conditions in the proposed landfill site, in addition to taking into consideration the suitability and data dependant factors.

During construction stage, the Erosion and Sedimentation Control Plan (ESCP) is generally regarded as a comprehensive plan designed to address the temporary and permanent mitigation of erosion and sedimentation hazards on disturbed soil surfaces. The objectives of ESCP are to implement temporary or permanent erosion and sedimentation mitigation measures. The plans also aim to identify, reduce, eliminate, or prevent the pollution of stormwater as well as the water quality of nearby watercourses by controlling peak rates and volumes of runoff outfalls and downstream of the outfalls.

\section{MATERIALS AND METHOD}

An integrated approach for the assessment of the soil erosion rate and sediment yield for different construction stages, and recommended appropriate mitigation measures for the project site is shown in Figure 2. Preliminary investigation and identification of the study area were carried out prior to the erosion analysis. In this study, RUSLE and MUSLE equations were used to estimate the soil erosion rates and sediment yields at the project site. The equations and the relevant factors are shown in Equation 1 to Equation 9.

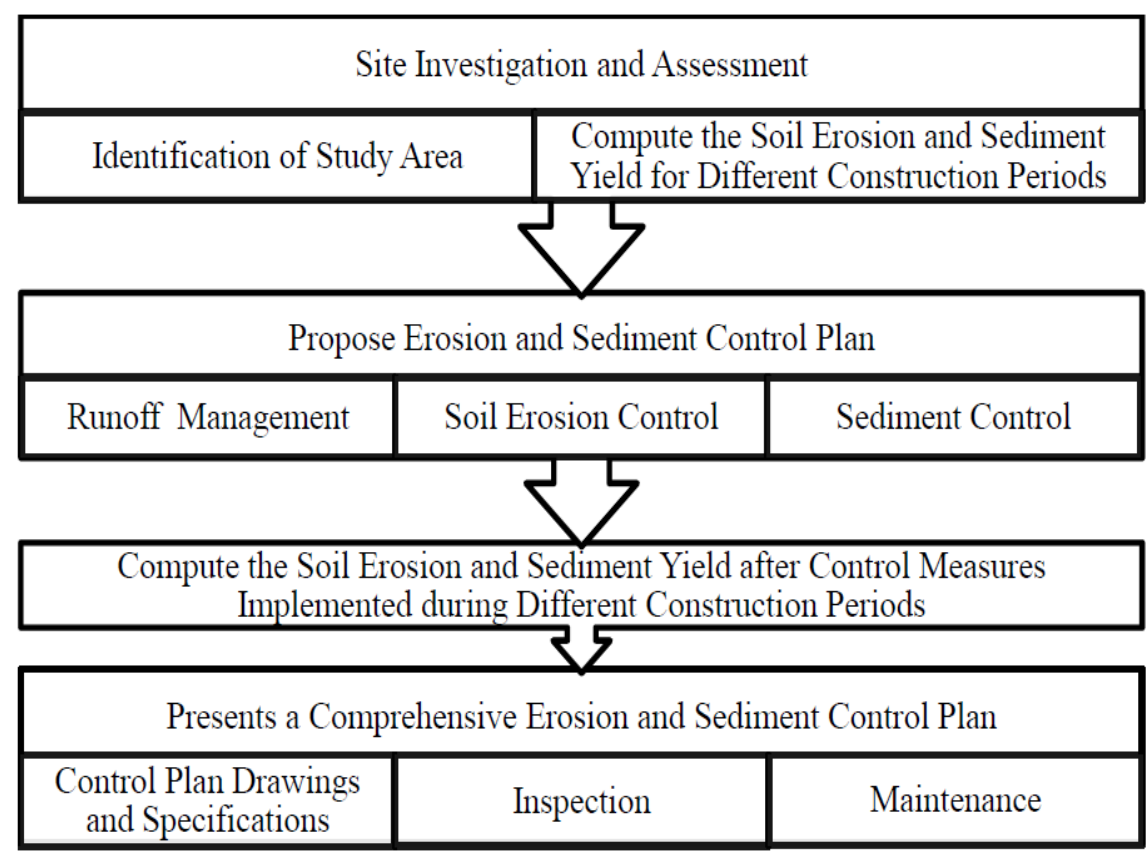

Figure 2: Erosion Rate and Sediment Yield and Mitigation Measures

Since comprehensive rainfall records are not available, the rainfall observations obtained from Jabatan Kerja Raya, Sibu, Sarawak was used to represent the rainfall condition at the landfill site, as it is the nearest rainfall station in Sibu Division or Central Zone of Sarawak. The R factor was estimated using Foster's Method as shown in Equation 2 [4]. The monthly average rainfall was used to determine the mean annual rainfall and the Rainfall Intensity-Duration-Frequency Curve for 30 minute in 5 years return period was used to estimate the $\mathrm{R}$ factor [6].

Due to the absence of empirical value, the $\mathrm{K}$ factor of a soil was determined from USDA Soil Erodibility Nomograph during pre-construction, construction, and operation stages [9]. The $\mathrm{K}$ factor is related to the class of land-component map on the basis of percentages of sand, silt, very fine sand, organic matters, soil structure and permeability [9]. The basis of percent of sand, percent of silt plus very fine sand parameters was determined from the soil particle size distribution analysis for the landfill site. The percentage of organic matters was obtained from the Test Report of the landfill site by taking the average percentage of organic matters content of the 16 borehole log data in the disturbed samples. The soil structure categories were determined from the USDA Soil Structure Classes [9]. The permeability value 
was estimated using borehole drilling test method and the results were compared to the USDA Soil Permeability Classes [9].

The landfill site is located on existing ground levels between 8.5-16.0 meters contour levels, and the site will be elevated to a design elevations ranging from $10.0-22.5$ meters contour level. Site stripping, excavation, and grading on exposes soil shall alter slope gradient and slope length. Therefore, the potential erosion and sedimentation shall most likely to occur along the project alignments during construction stage. During operation stage, slope length is generally not significant as the elevation is same as the design level. Therefore, the slope length (LS) during construction stage and operation stage shall be considered the same.

As shown in Figure 4 and Figure 5, a total of 13 different slope lengths for the individual "microcatchments" had been estimated in the process of determining the value of C during pre-construction, construction, and operation stages with reference to Cover Management Factor (C) for Construction Sites [10]. However, the P value was determined by using the Surface Condition for Construction Sites [10].

The peak flow, $\mathrm{Q}_{\mathrm{p}}$ was determined using Rational Formula by delineating the watershed boundary and computing the landfill area. Then the rainfall intensity, $i$ for the 5-Yr design storm was determined with reference to the IDF Curve [6]. The runoff coefficient was adopted from the Runoff Coefficients for Rational Equation to determine the peak flowrate, $\mathrm{Q}_{\mathrm{p}}[11]$.

Additionally, the SCS Curve Number Runoff Method was used to determine the volume of runoff by using the Runoff Curve Numbers for Undeveloped Land [10]. The Hydrologic Soil Groups (HSGs) in USDA Manual, 1986 describes the water absorption in soil after a period of prolonged wetting and the data were used to determine the $\mathrm{CN}$ values [10].

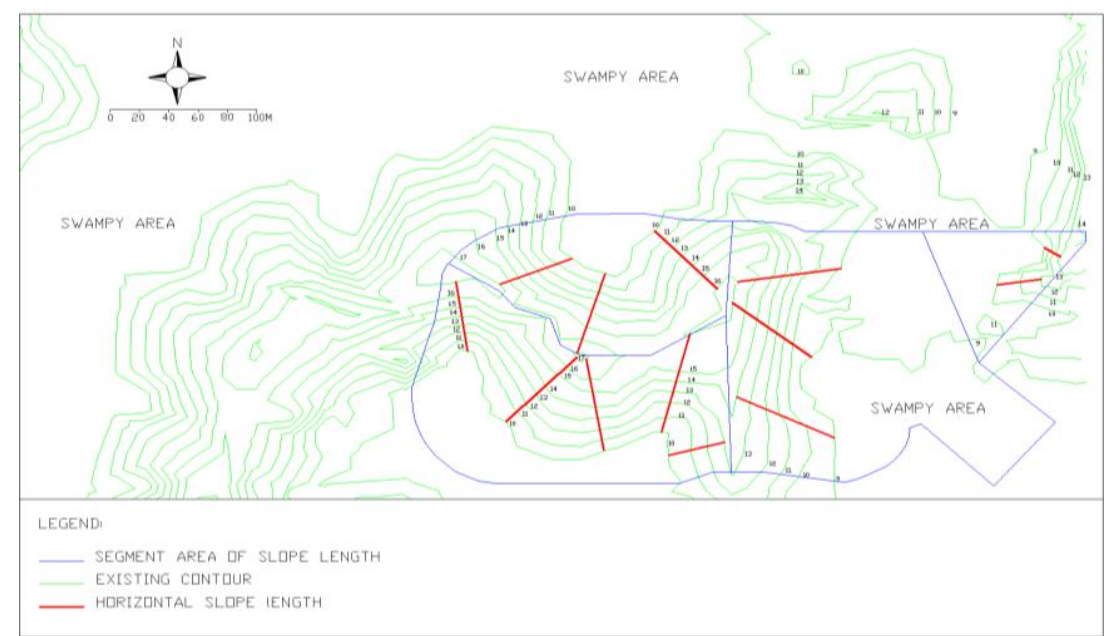

Figure 3: Estimated Slope Lengths during Pre-Construction Stage 


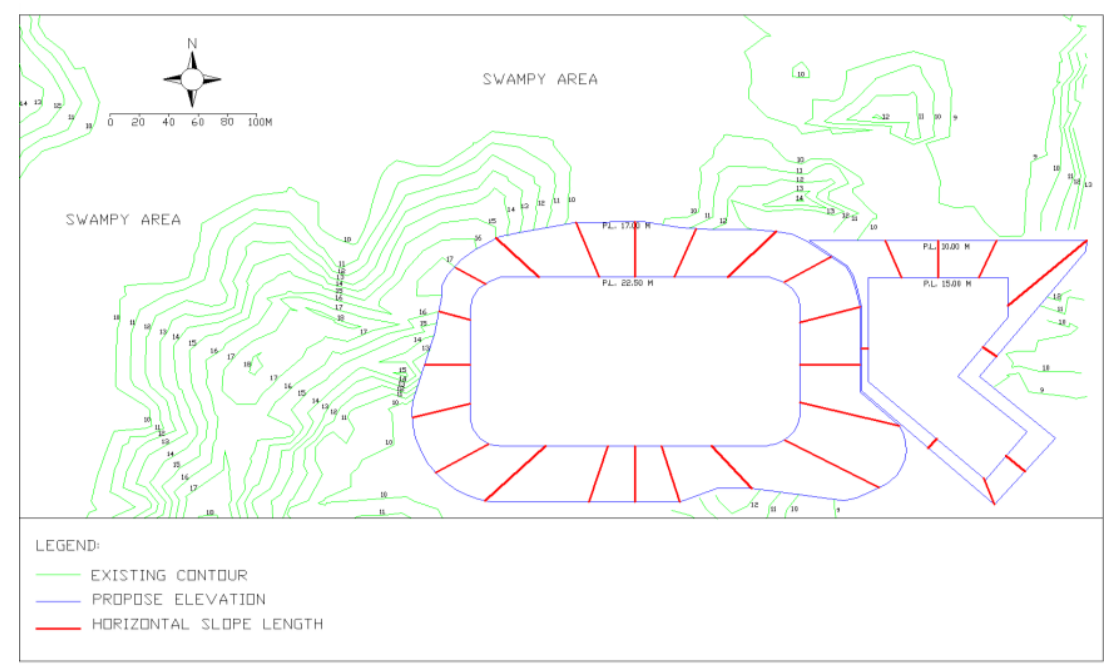

Figure 4: Estimated Slope Lengths during Construction Stage

\section{RESULTS AND DISCUSSION}

Soil erosion rates were estimated using the Revised Universal Soil Loss Equation (RUSLE), while sediment yields were predicted using the Modified Universal Soil Loss Equation (MUSLE). The mean annual rainfall in Year 2003 recorded at Sibu JKR Water Board Station was $270.54 \mathrm{~mm}$ for the region [6]. From the Rainfall Intensity-Duration-Frequency Curve, it was determined that the value of rainfall intensity, $I$ for 30 -minute 5 years return period was approximately $99 \mathrm{~mm} \cdot \mathrm{hr}^{-1}$. From Equation 2, the rainfall runoff erosivity, $\mathrm{R}$ was found to be $42.58 \mathrm{Mj} . \mathrm{mm}$.(ha.h.yr) ${ }^{-1}$.

Analysis on the soil samples collected from project site showed that the soil types ranged from very soft clay, clayed silt to firm sandy silt. The particle size distribution analysis showed that the average percentage of silt (including very fine sand), sand and organic matters were $78.59 \%, 1.22 \%$ and $0.128 \%$, respectively. The average soil permeability at landfill site was found to be $1.15 \times 10^{-5} \mathrm{~cm} . \mathrm{s}^{-1}$, and the K factor for the landfill site was 0.46 tons.ha.h.(ha.Mj.mm) ${ }^{-1}$.

The maximum LS values at site were found to be 3.16 during pre-construction stage and 3.59 during construction and operation stages. The soil at site would be disturbed during earthwork and the existing vegetation would have to be cleared and removed for cut-and-fill activities. Based on the Cover Management Factor (C) for Construction Sites, the C value of 0.01 would be used during preconstruction stage as an undisturbed condition [10]. During construction and operation stages, $\mathrm{C}$ value of 1.0 would be used for cleared or bare soil surfaces and no re-vegetation conditions.

Based on the Surface Condition for Construction Sites, when no activities are carried out on the landfill site, a default $\mathrm{P}$ value of 1.0 would be used [10]. During construction stage, construction activities such as grading, excavating, cutting and filling would disturb the soil by loosening the particles of soil and thus reducing the soil's shear strength, which may lead to surface runoff caused by heavy rain water. Thus, a $\mathrm{P}$ value of 1.3 would be used. After the construction period, considering the project site is rough, irregular surface equipment tracks in all directions, $\mathrm{P}$ value of 0.9 would be used.

The runoff coefficient, $C$ and the peak flow, $\mathrm{Q}_{\mathrm{p}}$ used in the Rational Formula was computed in Table 1 whilst the Runoff Curve Number, $\mathrm{CN}$ and Runoff Volume, V were calculated in Table 2 for different construction stages. Table 3 and Table 4 show the predicted soil erosion rates and sediment yields without control measures onsite during different construction stages, whilst Table 5 and Table 6 show the estimated soil erosion rates and sediment yields with BMP control measures onsite. The BMP control measures proposed for this research are stated in Table 7 for different construction stages whilst the proposed locations and methods of application are shown in Figures 5, 6, 7, 8 and 9.

As shown in Tables 2, 3, 4, 5 and 6, the potential soil erosion rates and sediment yields after implementation of BMPs control measures during different construction stages could effectively reduce the impacts from 91.4 and 954.8 to 1.62 and 24.8 tons.(ha.yr) ${ }^{-1}$, respectively. During operation stage, the 
soil erosion rates and sediment yields would decrease from 63.3 and 1042.4 to 0.54 and 14.9 tons.(ha.yr) ${ }^{1}$, respectively. According to the Classification of Soil Erosion Risk under Department of Environment [12], BMP is very effective and able to reduce the potential soil loss from Moderate-High Soil Loss Risk to Low Risk, as shown in Table 8. With BMP onsite, it was showed that a decrease of $97.4 \%$ in soil erosion rate and more than $98 \%$ sediment reduction during both the construction and operation stages.

Table 1: Runoff Coefficient, $C$ and Peak Flow, $Q_{p}$ vs Construction Stage

\begin{tabular}{|c|c|c|c|c|c|c|c|}
\hline Stage & Area $\left(\mathbf{m}^{2}\right)$ & $\begin{array}{c}\text { Area } \\
\text { (ha) }\end{array}$ & $\begin{array}{c}\text { Average } \\
\text { slope }\end{array}$ & $\begin{array}{c}\text { Coefficient, } \\
\text { C }\end{array}$ & $\begin{array}{c}\text { Rainfall } \\
\text { Intensity, I } \\
\left(\mathbf{m m} \cdot \mathbf{h r} \mathbf{r}^{-1}\right)\end{array}$ & $\begin{array}{c}\text { Peak Flow, } \\
\mathbf{Q}_{\mathbf{p}}\left(\mathrm{m}^{\mathbf{3}} \cdot \mathrm{s}^{-1}\right)\end{array}$ & Total \\
\hline \multirow{3}{*}{ Pre -Construction } & 14720.64 & 1.472 & 0.11 & 0.2 & 99 & 0.081 & \multirow{3}{*}{0.415} \\
\hline & 24302.70 & 2.430 & 0.10 & 0.2 & 99 & 0.134 & \\
\hline & 36493.17 & 3.649 & 0.12 & 0.2 & 99 & 0.201 & \\
\hline \multirow{2}{*}{ Construction } & 17426.68 & 1.743 & 0.17 & 0.5 & 99 & 0.240 & \multirow{2}{*}{1.038} \\
\hline & 58089.83 & 5.809 & 0.17 & 0.5 & 99 & 0.799 & \\
\hline \multirow{2}{*}{ Operation } & 17426.68 & 1.743 & 0.17 & 0.6 & 99 & 0.288 & \multirow{2}{*}{1.246} \\
\hline & 58089.83 & 5.809 & 0.17 & 0.6 & 99 & 0.958 & \\
\hline
\end{tabular}

Table 2: Runoff Curve Number, CN and Runoff Volume, V vs Construction Stage

\begin{tabular}{|l|c|c|c|c|c|c|c|c|c|}
\hline \multicolumn{1}{|c|}{ Stage } & $\begin{array}{c}\text { Rainfall } \\
\text { Depth } \\
(\mathbf{m m})\end{array}$ & $\begin{array}{c}\text { Rainfall } \\
\text { Depth } \\
\text { (in) }\end{array}$ & HSGs & CN & S & $\begin{array}{c}\text { Runoff } \\
\text { Depth, } \\
\mathbf{Q}(\mathbf{i n})\end{array}$ & $\begin{array}{c}\text { Runoff } \\
\text { Depth } \\
(\mathbf{m})\end{array}$ & $\begin{array}{c}\text { Area of } \\
\text { Site }\left(\mathbf{m}^{\mathbf{2}}\right)\end{array}$ & $\begin{array}{c}\text { Runoff } \\
\text { Volume } \\
\left(\mathbf{m}^{\mathbf{3}}\right)\end{array}$ \\
\hline $\begin{array}{l}\text { Pre- } \\
\text { Construction }\end{array}$ & 49.5 & 1.95 & $\mathrm{D}$ & 86 & 1.628 & 0.811 & 0.021 & 75516.51 & 1556.24 \\
\hline $\begin{array}{l}\text { During } \\
\text { Construction }\end{array}$ & 49.5 & 1.95 & $\mathrm{D}$ & 74 & 3.514 & 0.327 & 0.008 & 75516.51 & 626.81 \\
\hline Operation & 49.5 & 1.95 & $\mathrm{D}$ & 82 & 2.195 & 0.616 & 0.016 & 75516.51 & 1181.61 \\
\hline
\end{tabular}

Table 3: Predicted Soil Erosion Rates vs Construction Stages (without Control Measures)

\begin{tabular}{|l|c|c|c|c|c|c|}
\hline \multicolumn{1}{|c|}{ Stage } & R [Mj.mm.(ha.h.yr) $\left.{ }^{-\mathbf{1}}\right]$ & $\begin{array}{c}\text { K } \\
\left.\text { [tons.ha.h.(ha.Mj.mm) })^{-1}\right]\end{array}$ & LS & C & $\begin{array}{c}\text { P } \\
\text { RUSLE } \\
\text { (tons. }\{\mathbf{h} \\
\mathbf{a . y r}\}^{-1} \text { ) }\end{array}$ \\
\hline Pre-construction & 42.58 & 0.46 & 3.16 & 0.01 & 1 & 0.619 \\
\hline $\begin{array}{l}\text { During Construction } \\
\text { Without Control }\end{array}$ & 42.58 & 0.46 & 3.59 & 1.0 & 1.3 & 91.412 \\
\hline Operation Stage & 42.58 & 0.46 & 3.59 & 1.0 & 0.9 & 63.285 \\
\hline
\end{tabular}

Table 4: Predicted Sediment Yields vs Construction Stages (Without Control Measures)

\begin{tabular}{|l|c|c|c|c|c|c|c|}
\hline \multicolumn{1}{|c|}{ Stage } & $\begin{array}{c}\mathbf{Q}_{\mathbf{p}} \\
\left(\mathbf{m}^{\mathbf{3}} \cdot \mathbf{s}^{-1}\right)\end{array}$ & $\mathbf{V},\left(\mathbf{m}^{\mathbf{3}}\right)$ & $\begin{array}{c}\mathbf{K} \\
\text { [tons.ha.h.(ha.Mj.mm) }{ }^{-\mathbf{1}} \text { ] }\end{array}$ & $\mathbf{L S}$ & $\mathbf{C}$ & $\begin{array}{c}\text { P } \\
\text { MUSLE } \\
\text { (tons) }\end{array}$ \\
\hline Pre-construction & 0.415 & 1556.24 & 0.46 & 3.16 & 0.01 & 1 & 6.43 \\
\hline $\begin{array}{l}\text { During Construction } \\
\text { Without Control }\end{array}$ & 1.038 & 628.81 & 0.46 & 3.59 & 1.0 & 1.3 & 954.81 \\
\hline Operation Stage & 1.246 & 1181.61 & 0.46 & 3.59 & 1.0 & 0.9 & 1042.44 \\
\hline
\end{tabular}


Table 5: Soil Erosion Rates with Implementation of BMP Control Measures

\begin{tabular}{|c|c|c|c|c|c|c|c|c|c|c|c|}
\hline \multirow[b]{2}{*}{ Stage } & \multirow[b]{2}{*}{$\mathbf{R}$} & \multirow[b]{2}{*}{$\mathbf{K}$} & \multirow[b]{2}{*}{$\mathbf{L S}$} & \multirow[b]{2}{*}{ C } & \multirow[b]{2}{*}{$\mathbf{P}$} & \multicolumn{5}{|c|}{ Effectiveness of Sediment Control Factor } & \multirow[b]{2}{*}{$\begin{array}{c}\text { RUSLE } \\
\text { (tons. }\{\text { ha } \\
\left.. \mathbf{y r}\}^{-1}\right)\end{array}$} \\
\hline & & & & & & $\begin{array}{l}\text { Earth } \\
\text { Bund }\end{array}$ & $\begin{array}{c}\text { Silt } \\
\text { Fence }\end{array}$ & $\begin{array}{c}\text { Silt } \\
\text { Trap }\end{array}$ & $\begin{array}{l}\text { Check } \\
\text { dams }\end{array}$ & $\begin{array}{c}\text { Stabilized } \\
\text { Construction } \\
\text { Exit }\end{array}$ & \\
\hline $\begin{array}{l}\text { During } \\
\text { Construction } \\
\text { Without } \\
\text { Control }\end{array}$ & 42.58 & 0.46 & 3.59 & 0.1 & 1.0 & 0.95 & 0.95 & 0.85 & 0.4 & 0.75 & 1.618 \\
\hline $\begin{array}{l}\text { Operation } \\
\text { Stage }\end{array}$ & 42.58 & 0.46 & 3.59 & 0.01 & 0.9 & - & - & 0.85 & - & - & 0.538 \\
\hline
\end{tabular}

Table 6: Sediment Yields with Implementation of BMP Control Measures

\begin{tabular}{|c|c|c|c|c|c|c|c|c|c|c|c|c|}
\hline \multirow[b]{2}{*}{ Stage } & \multirow[b]{2}{*}{$\mathbf{Q}_{\mathbf{p}}$} & \multirow[b]{2}{*}{$\mathbf{V}$} & \multirow[b]{2}{*}{$\mathbf{K}$} & \multirow[b]{2}{*}{$\mathbf{L S}$} & \multirow[b]{2}{*}{$\mathbf{C}$} & \multirow[b]{2}{*}{$\mathbf{P}$} & \multicolumn{5}{|c|}{ Effectiveness of Sediment Control Factor } & \multirow[b]{2}{*}{$\begin{array}{c}\text { MUSLE } \\
\text { (tons) }\end{array}$} \\
\hline & & & & & & & $\begin{array}{l}\text { Earth } \\
\text { Bund }\end{array}$ & $\begin{array}{c}\text { Silt } \\
\text { Fence }\end{array}$ & $\begin{array}{c}\text { Silt } \\
\text { Trap }\end{array}$ & $\begin{array}{l}\text { Check } \\
\text { dams }\end{array}$ & $\begin{array}{c}\text { Stabilized } \\
\text { Construction } \\
\text { Exit }\end{array}$ & \\
\hline $\begin{array}{l}\text { During } \\
\text { Construction } \\
\text { Without } \\
\text { Control }\end{array}$ & 1.038 & 628.81 & 0.46 & 3.59 & 0.1 & 1.0 & 0.95 & 0.95 & 0.85 & 0.4 & 0.75 & 24.806 \\
\hline $\begin{array}{l}\text { Operation } \\
\text { Stage }\end{array}$ & 1.246 & 1181.61 & 0.46 & 3.59 & 0.01 & 0.9 & - & - & 0.85 & - & - & 14.928 \\
\hline
\end{tabular}

Table 7: Proposed Erosion and Sediment Control Measures

\begin{tabular}{|c|c|c|}
\hline BMPs Control Measures & $\begin{array}{c}\text { Construction } \\
\text { Stage } \\
\end{array}$ & $\begin{array}{c}\text { Operation } \\
\text { Stage } \\
\end{array}$ \\
\hline \multicolumn{3}{|c|}{$\underline{\text { Sediment Control }}$} \\
\hline Silt Fence & $\sqrt{ }$ & \\
\hline Check Dams & $\sqrt{ }$ & \\
\hline Silt Trap & $\sqrt{ }$ & $\sqrt{ }$ \\
\hline Stabilized Construction Exits & $\sqrt{ }$ & \\
\hline \multicolumn{3}{|c|}{$\underline{\text { Erosion Prevention Controls }}$} \\
\hline Seeding / re-vegetation / turfing & $\sqrt{ }$ & $\sqrt{ }$ \\
\hline Appropriate Earthwork Operation & $\sqrt{ }$ & \\
\hline
\end{tabular}

Table 8: Classification of Potential Soil Loss

\begin{tabular}{|l|c|}
\hline \multicolumn{1}{|c|}{ Classification of Soil Loss } & Potential Soil Loss/Erosion Rate (tons/ha/yr) \\
\hline Low & $0-10$ \\
\hline Moderate & $10-50$ \\
\hline Moderate High & $50-100$ \\
\hline High & $100-150$ \\
\hline Very High & Above 150 \\
\hline
\end{tabular}


Source: State Environmental Conservation Department (ECD), Sabah, Malaysia

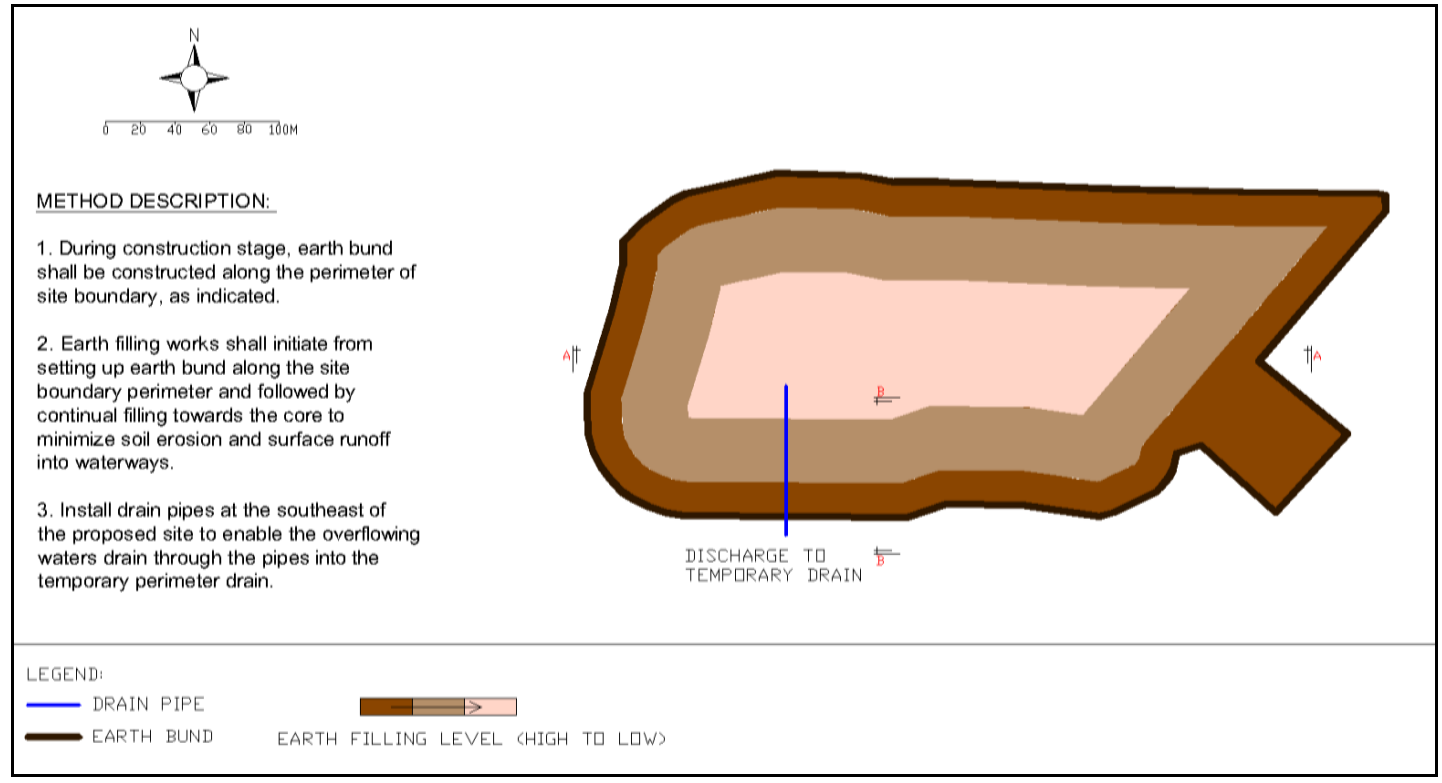

Figure 5: Temporary Earth Filling Method

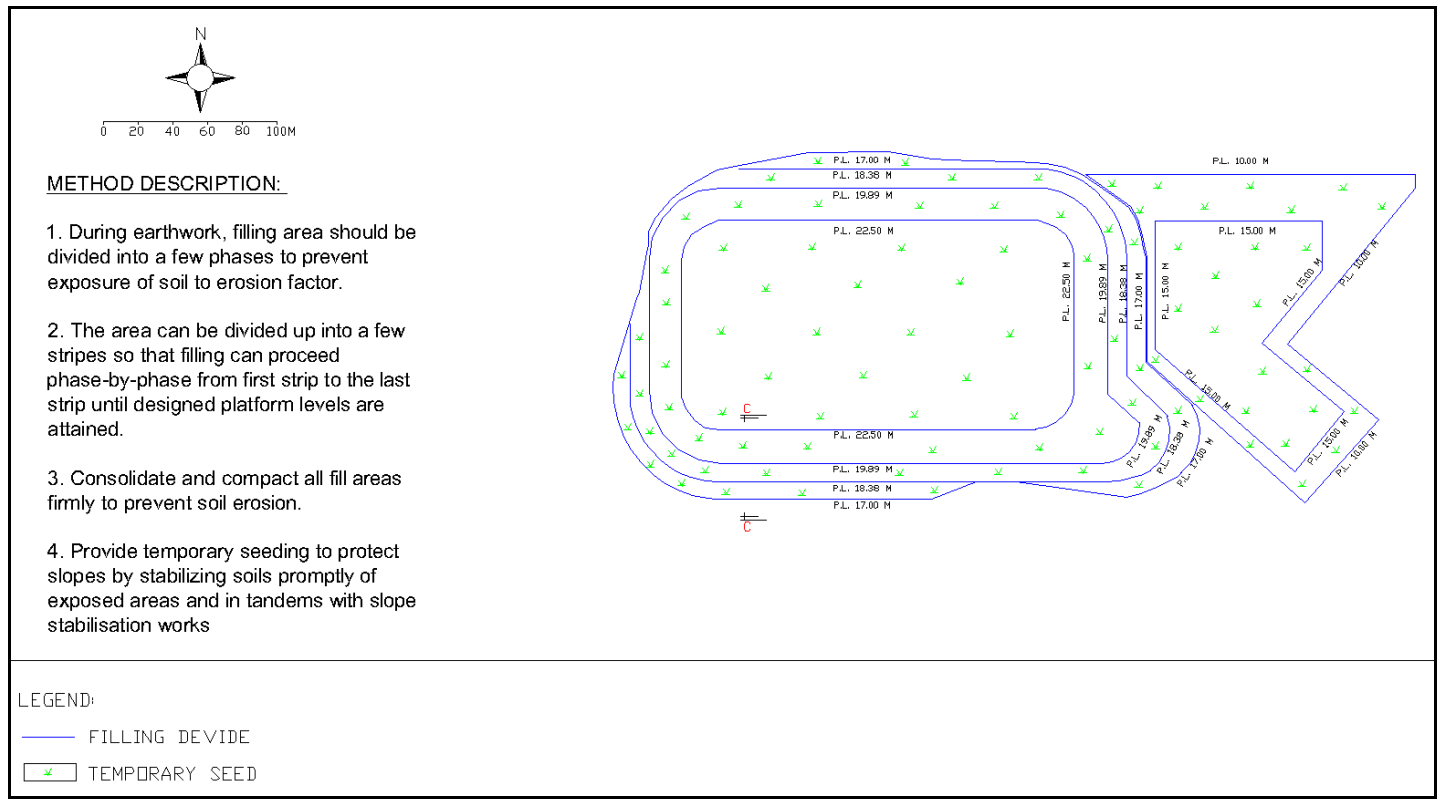

Figure 6: Temporary Phasing of Filling \& Seeding Area 
UNIMAS E-Journal of Civil Engineering, Vol. 2 (2) 2011

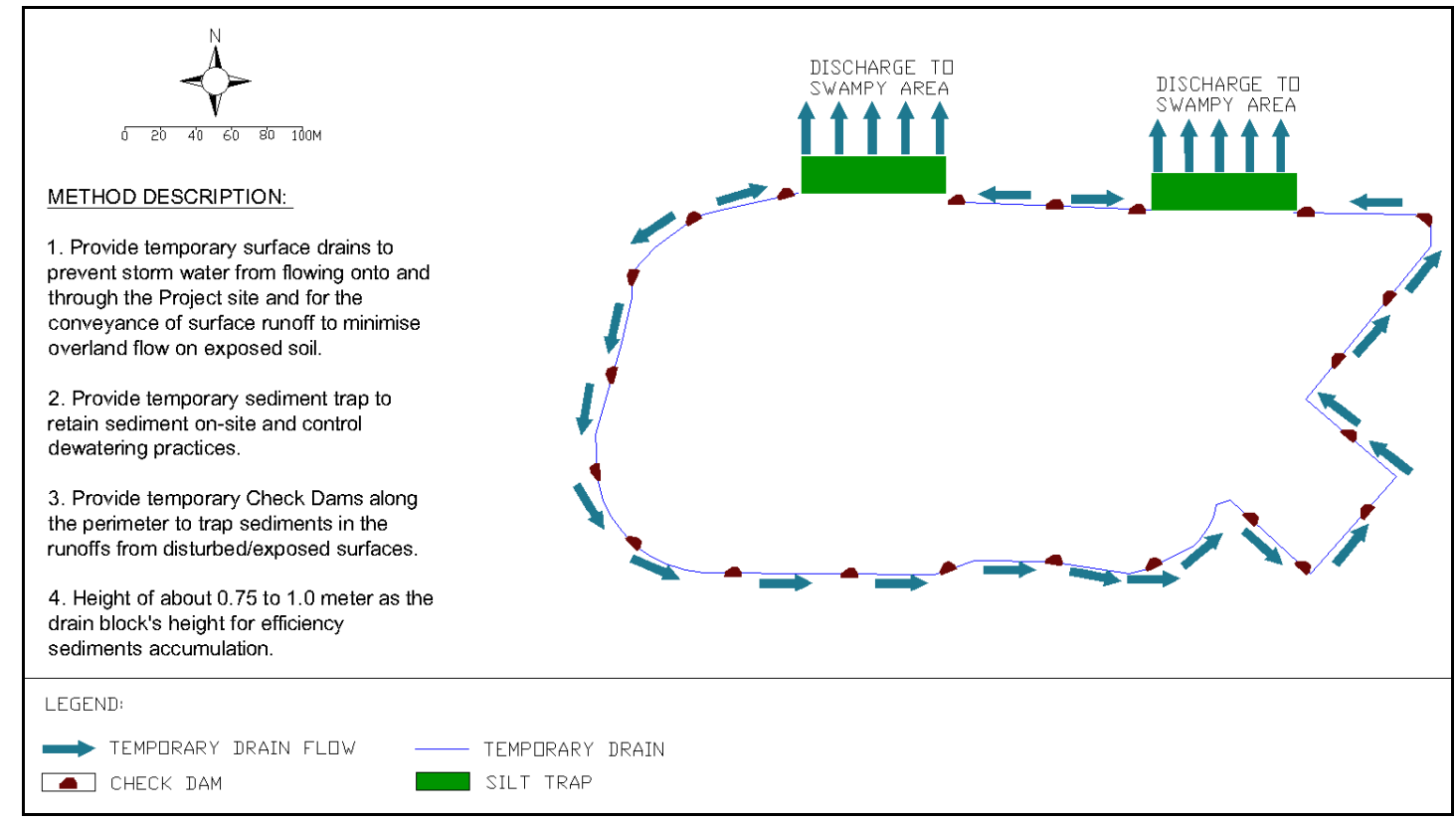

Figure 7: Temporary Earth drain, Silt Trap and Check Dams

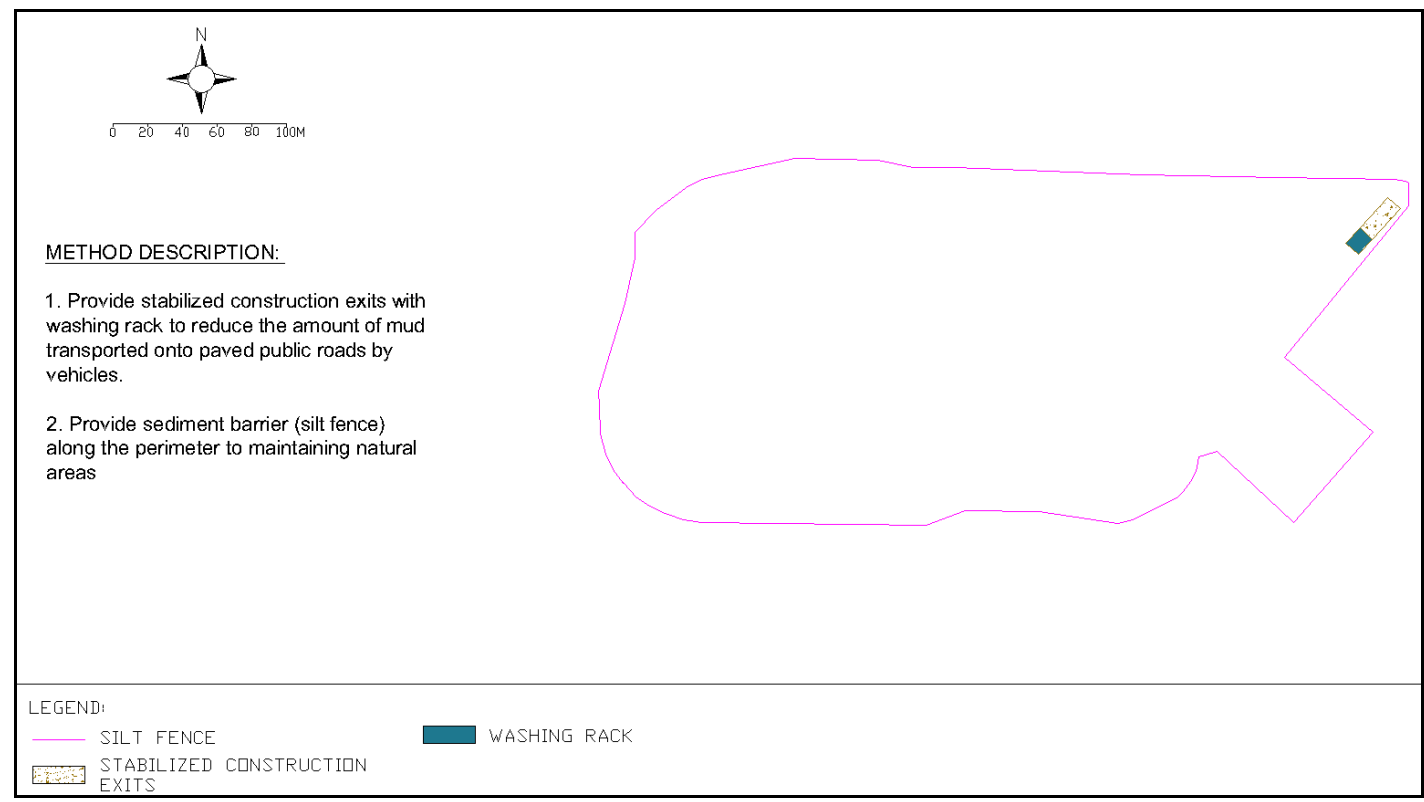

Figure 8: Temporary Stabilized Construction Exits and Silt Fence along Site Boundary 


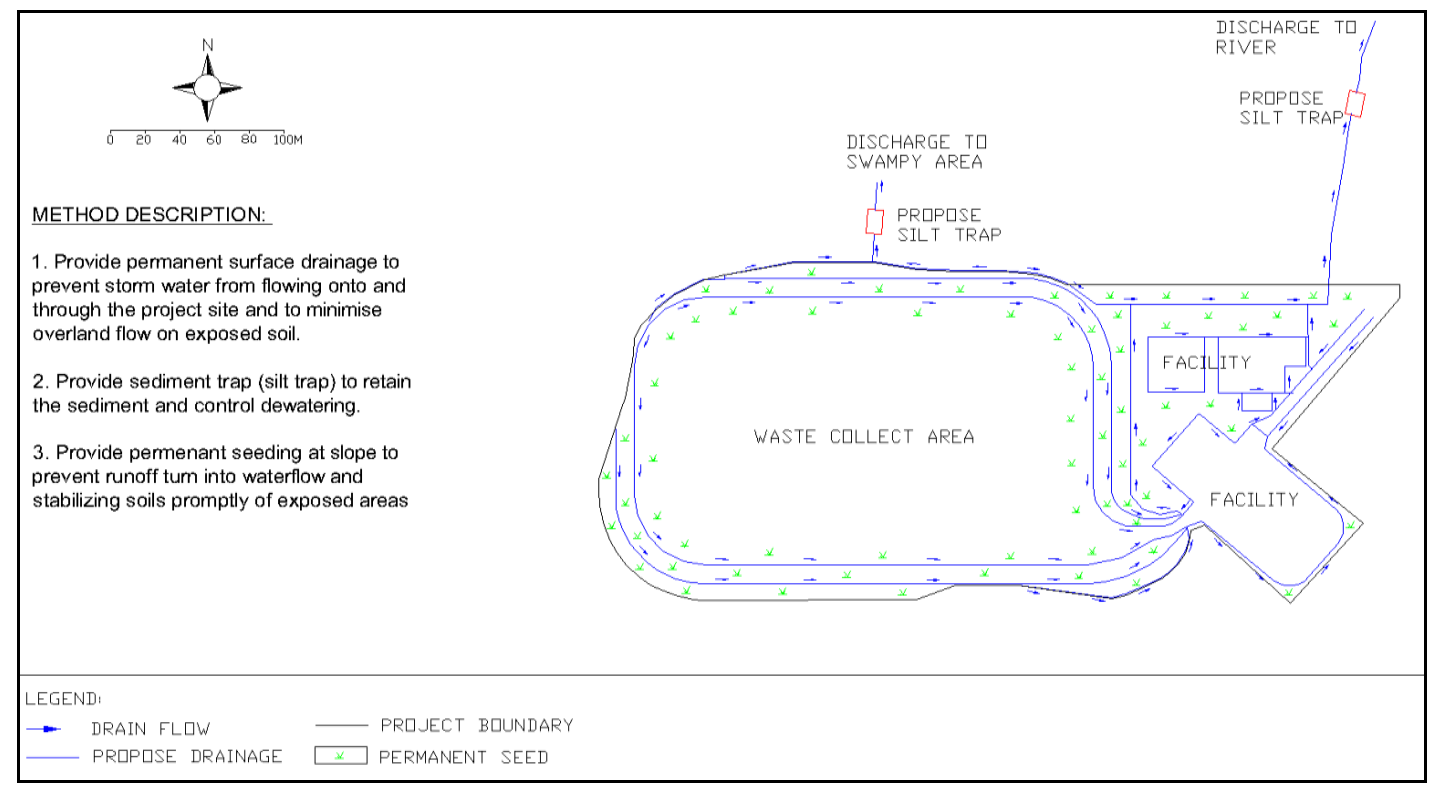

Figure 9: Permanent Seeding, Drainage, and Silt Trap Systems

\section{CONCLUSIONS}

With BMP control measures onsite, the soil erosion rates during construction and operation stages could be reduced from "Moderate-High Soil Loss Class" (between $50-100$ tons. $\{\text { ha.yr }\}^{-1}$ ) to "Low Soil Loss Class" (between $0-10$ tons. \{ha.yr ${ }^{-1}$ ). Similarly, after implementing BMP control measures onsite, sediments yields on a single storm event during construction can be reduced from 954.81 to 16.90 tons/storm event, and during operation stage from 1,042.44 to 8.86 tons/storm event. It can also be concluded that the most effective factor to reduce the potential of soil erosion rates and sediment yields was proper cover management. The implementation of seeding has shown a significant decrease in soil erosion rate and sediment yield due to its effectiveness in resisting rainfall impact through soil stabilizing effects caused by roots, and thus enhance sediment trapping capability and finally slowing down the runoff of both water and sediments.

\section{ACKNOWLEDGMENT}

The authors wish express their gratitude to Universiti Malaysia Sarawak for the support in this research.

\section{REFERENCES}

[1] Brooks, S.R. and Spencer, T. (1993). Tropical Rain Forest Logging: Modeling Slope Processes and Soil Erosion in Sabah, East Malaysia. Journal of Tropical Geography, 15-27.

[2] Department of Irrigation and Drainage (DID). (2001). Urban Stormwater Management Manual for Malaysia. Department of Irrigation and Drainage.

[3] Wischmeier, W. and Smith, D. (1978). Predicting rainfall erosion-losses. In A guide to Conservation Planning (pp. 58). Washington, D.C: Agricultural Handbook No. 537.

[4] Foster, G.R. and Lane, L.J. (1981). Erosion and Sediment Yield on Field-Sized Areas. Transactions of the ASAE, 24.

[5] Williams, J. (1975). Sediment Yield Prediction with Universal Equation Using Runoff Energy Factor. In Present and Prospective Technology for Predicting Sediment Yields and Source (pp. 244-252). Washinton D.C.: ARS-S-40, 1976.

[6] Department of Irrigation and Drainage (DID). (2003). Sarawak Hydrology Year Book, Malaysia.

[7] Prodanovic, P. and Simonovic, S. (2007). Water Resources Research Report. London: The University of Western Ontario, Department of Civil and Environmental Engineering.

[8] Missouri. (2007). Drainage Criteria Manual. City of Springfield: Missouri, USA 
[9] Wishmeier, W. H. and Johnson, C. B. (1971). A Soil Erodibility Nomograph for Farmland and Construction Sites. Journal of Soil and Water Conservation, 26, 189- 192.

[10] Certified Professional in Erosion and Sediment Control (CPESC). (2010). Environmental Institute of Malaysia (EiMAS), Department of Environmental, Ministry of Natural Resources and Environment, Universiti Kebangsaan Malaysia, Malaysia.

[11] Bureau of Watershed Management. (2000). Erosion and Sediment Pollution Control Program Manual. Department of Environmental Protection Office. California Stormwater Quality Association, California, USA.

[12] Environmental Impact Assessment (EIA) Guidelines Oil Palm Plantation Development (2000). 3rd Draft. State Environmental Conservation Department (ECD), Sabah, Malaysia 